\title{
Method of Vertical Cross Configuration in Optimizing Potential of Paper Waste and Dry Leafs as a Base Material for Producing Comboard
}

\author{
Firman Hawari* Agus Sachari Adhi Nugraha \\ Faculty of Fine Art and Design, Bandung Institute of Technology, Jl Ganesha 10, Bandung - 40132
}

\begin{abstract}
This research starts with motivation to reduce dependence on natural materials in construction works especially at interior design. Another thing is a quick look at the amount of waste paper and dry leafs in every corner of the city which can mean that the basic ingredients will be sufficient for production activities. It is these two things that encourage production of materials like panel to support construction activities. Whay? Because panels are main raw material for housing construction which continues to grow and community demand is large every year. This thinking gives an idea of making a comboard. Structurally, comboard is a panel product with an inner structure made of paper and outer structure / layer is composed of dry leafs. The resulting shape can produce a combination board as a panel material that has a functional and aesthetic value. In general, the creating direction of a comboard panel is directed to producing panel that is suitable for use, and can be accountable for as a construction and aesthetic material in interior implementation. Utilization is expected to provide added value to paper waste and dry leafs as a potential material that is not only as a waste variable that pollutes the city. To compile and shape paper waste and dry leaf into comboard products, a number of forming experiments were done and composing these limp and fragile waste sheets into solid, strong and sturdy panels. From several experiments that's been conducted, it produced one precise and accurate production pattern in making the structure and surface of the panel from the waste sheets. This production pattern is called the method of vertical cross configuration. The reason for this method is perception of solid form and development of form and function afterwards. So focus of this study is to discuss how to arrange vertical crosses that are used to arrange sheets of paper and dry leafs into comboard products that are able to do well and correctly by method vertical cross configuration.
\end{abstract}

Keywords: vertical cross configuration, visual image, comboard, panel function

DOI: $10.7176 / \mathrm{ADS} / 79-03$

Publication date: December $31^{\text {st }} 2019$

\section{Introduction}

Dependence on natural materials, mainly wood, raises concerns about its availability in the future. Ideally, wood can be cut down in the 45-60 year planting period when wood reaches physical maturity to be used as design and building material. For this reason, large-scale exploration is carried out to meet market needs so high at that time. And now wood with ' $A$ ' quality like that is very difficult to find and then what happens is that wood with a duration of 4-5 years is being targeted for logging because the reforestation process is not as it should be. This makes it difficult to use 'A' quality wood to improve the quality of its products. Some research is conducted to find alternative materials to meet production needs and get the best product quality. For example making wood panels. But due to availability of wood material which is getting thinner, further research and experiments are conducted to make up panel from other materials. The consideration is due to flexibility of panel utilization, ease of use, opportunities for use and visualization of the outer surface. For this reason, this research and study was conducted. The material choice of waste paper and dry leaf is based on several considerations, including: abundant amount (which means guaranteed supply), easy to find, sheets form, and strong character. During this time, dry leaves and paper waste have been perceived as objects that have no use and benefits so that are leftover objects that are ignored. Physically, dry leafs known have brittle and cracked specifications, while paper waste has weak specifications. Both types of waste are independent and do not have the structural ability for any function. But without realizing it, dry leafs and waste paper have advantages that are not easily found in other types of objects, namely: large amounts, cheap, and easy to obtain. These advantages provide benefits of developing its benefits. So far, waste paper has only been used as recycled paper for various crafts, while dry leafs are used as compost to fertilize plants, but the economic value of both is still very low.

As example, data base of the Regional Clean Company (PD) of the City of Bandung in 2016 shows that garbage in the city of Bandung reached 1,500 - 1,600 tons / day by 2.4 million residents. Only 250 tons have been processed, most have not yet been processed (Kompas.com, week 21/82016). The composition consists of $60 \%$ organic waste and $40 \%$ inorganic waste (Metrotvnews.com, Tuesday 2/9'2016). Related to the volume of paper waste (including inorganic waste), the calculation can be found: $(1300 \times 40 \%) \times 10 \%=52$ tons /day. Meanwhile, remaining garbage, contains calculations: $(1300 \times 60 \%) \times 10 \%=78$ tons /day. It can be seen that paper waste and dry leafs in only one city, Bandung, shows promising potential for use in activities that invite product combinations. 
While there are still many other potential cities that have not been recorded.

Initially first panel product produced was dry leaf board and next one was paper board. Capability tests will be discussed in the discussion section. From the results of laboratory trials, it was obtained that paper can make a stronger structure than dry leaf and dry leaf has visual ability to be used as an outer lamination material. Based on that, an idea emerged to combine two according to ability. Next process of this idea creates a comboard.

\section{Vertical Cross Configuration}

Three-dimensional design consists of concept elements, including: points, lines, fields, and solid. The idea of forming panels from waste materials was obtained from 'solid' perception of Wucius Wong. Solid as a concept has length, width, and height, without weight, determining a large space it contains or occupies. Other concept said that density is also expressed by a series of fields or calculated fields make solids.
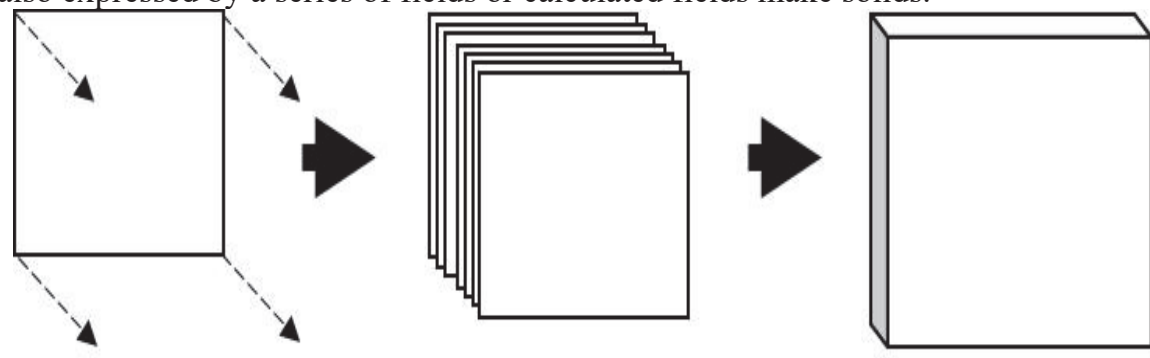

Figure 1 Solid process

Wong said that spacing can be narrow or wide, with different faces. Narrow spacing gives an impression of density/solid while wide spacing weakens an impression of solid. From this it follows that fields that are sticking will form a density. It is this solid forming process that underlies an initial idea of arranging vertical-horizontal crossing to make panels from waste paper and dry leafs. Therefore, in this experimental activities, the first step is observing the sheets of paper and dry leafs to make structural patterns and planning of visual surface slabs that are technically and aesthetically responsible. Character understanding of the sheet will greatly help determine pattern of treatment of basic materials, plan shape and volume that can be achieved, create a system/production flow, and selection of supporting materials and tools.

Some of experiments carried out provide a basic idea about structure arrangement of vertical plane. This pattern emphasizes density and strength on each sheet of municipal waste material used. Vertical ability provides chance of strength on flat planes produced by gluing together pieces of base material. This is the opinion that underlies a discussion on composition application of panel production in this study. The basic idea of preparing this vertical field can be seen in the following chart.

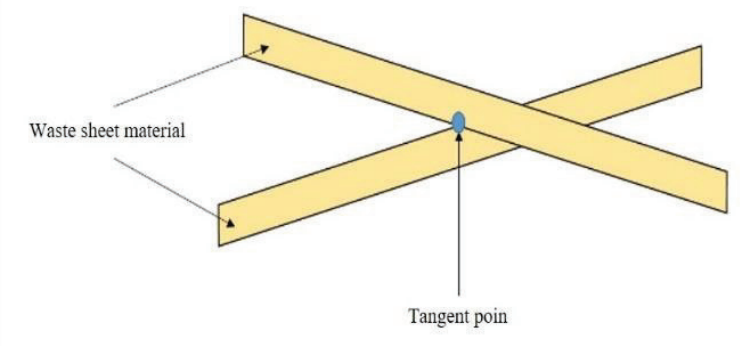

Figure 2 Basic idea of vertical cross configuration

Next experiments relate to pattern of cross structures. Ability test of balance on meeting point of each base material with a transverse vertical position to support and push each other. Furthermore, development of this idea is followed up in more detail by applying basic idea by using base material of rubbish supported by polychloroprene adhesive glue which is included in thermoplastic category which is environmentally friendly. In this follow-up experiment, sheets are vertically positioned and glued together tightly together, and without gaps so as to produce a solid shape as panel. Wong also mentioned that distance between narrow fields is impressively solid while wide distances weaken impression of solid. Narrow spacing can also be connoted by 'sticking'. From this experiment, a panel structure pattern produced from dry leafs and paper waste with a thickness of $20 \mathrm{~mm}$ that is hard, sturdy, and strong. 


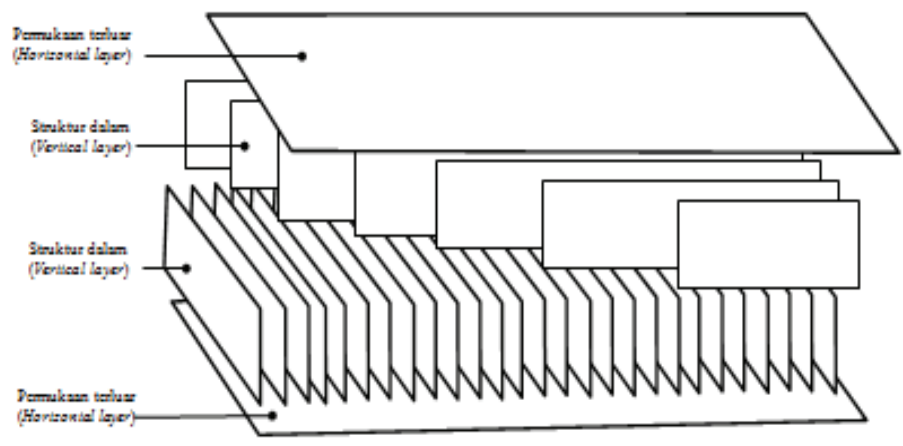

Gambar 3 Chart of vertical cross configuration

Structurally, vertical cross configuration consists of 4 layers, including:

a. Two layers of internal structure : each of which is made from pieces of paper waste that have been cut and arranged vertically. arrangement of layers is supported by polychloroprene adhesives. Both layer that is produced is then composed cross-linked and glued together.

b. Two layers of surface : outer layer of panel covering sides of two inner structures that have been glued together. Both layer is made from dry leaf. Arrangement of outer layer is done horizontally. Gluing using polychloroprene adhesive.

From this experiments that have been carried out, obtained advantages and disadvantages on application of vertical cross-configuration, including:

Tabel 1 advantages and disadvantages

\begin{tabular}{|l|l|}
\hline Advantages & Disadvantages \\
\hline Abundant basic ingredient & $\begin{array}{l}\text { Character of basic ingredient is not } \\
\text { necessarily same }\end{array}$ \\
\hline Adequat stuctural strength & Long manufacturing time \\
\hline Easy treatment & Requires skill talent \\
\hline Various application opportunity & Limited finishing \\
\hline Promising economic value & - \\
\hline
\end{tabular}

\section{1 Dry leaf board}

Initially this research produced dry leaf board. This panel is made by method of vertical cross configuration method with whole base material are dry leaf with an adhesive using polychloroprene. Dry leaf board has a thickness: 20 $\mathrm{mm}$ dan $10 \mathrm{~mm}$.
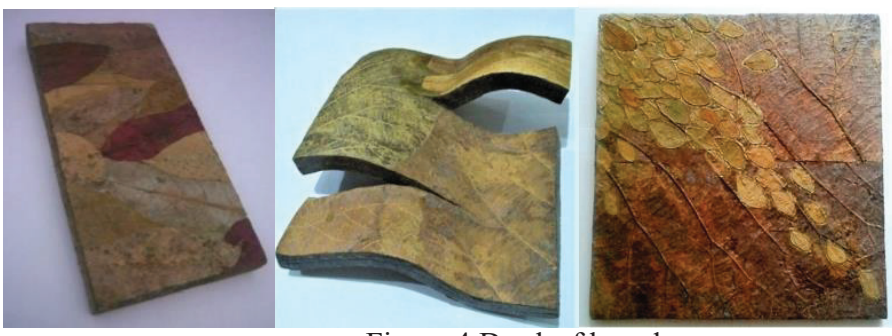

Figure 4 Dry leaf board

Physically, dry leaf board has waterproof capability and treatment capability like wood panel in general. The following are results of laboratory tests related to ability of dry leaf board:

Tabel 2 Test results of dry leaf board in laboratory

\begin{tabular}{|l|l|l|}
\hline \multicolumn{1}{|c|}{ Spesification } & Compressive test & Flextural test \\
\hline Thickness $: 22 \mathrm{~mm}$, wide $: 22 \mathrm{~mm}$, cross-sectional area $: 433,6 \mathrm{~mm} 2$ \\
\hline Withstand compressive loads & Max. 9,8 ton & - \\
\hline Compressive strength & $2,32 \mathrm{MPa}$ & - \\
\hline Wide $: 20,5$, tinggi $: 13,4$, foot length $: 150 \mathrm{~mm}$ \\
\hline Bear the weight & - & $395,9 \mathrm{~kg}$ \\
\hline Flexural strength & - & $24,16 \mathrm{~kg} / \mathrm{mm} 2$ \\
\hline
\end{tabular}




\section{2 Paper board}

The next stage of implementing method of vertical cross configuration is to produce a paper board. Paper board is a panel that is also made from whole raw material from waste paper material with polychloroprene adhesive. There are two types of thickness that can be produced namely $20 \mathrm{~mm}$ and $10 \mathrm{~mm}$ depending on needs. The basic properties of paper panels are rigid, rigid, sturdy, and not water resistance.

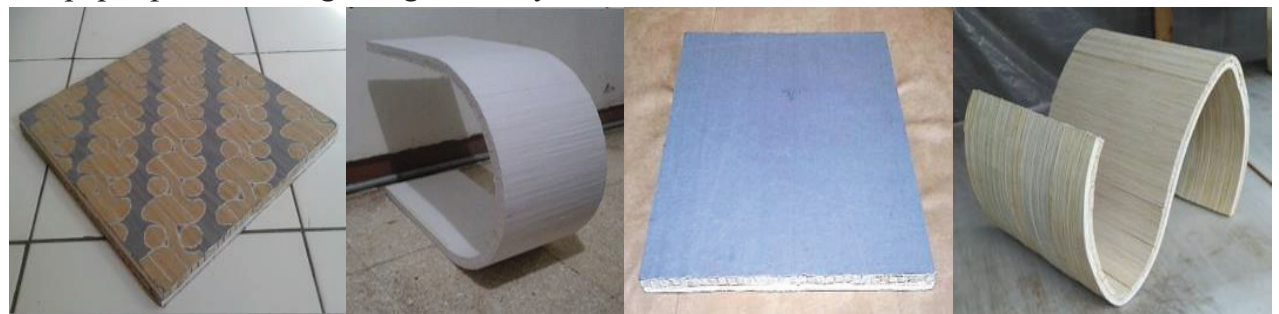

Considering importance of the basic form of configuration that forms solid, the required paper waste criteria is in the form of sheets. The character sheet will facilitate process coupling the deeper structure. The paper criteria sought area. While results of laboratory tests, paperboard has some following qualifications:

Tabel 3 Test results of paper board in laboratory

\begin{tabular}{|l|l|l|}
\hline \multicolumn{1}{|c|}{ Spesification } & Compressive test & Flextural test \\
\hline Thickness $: 21 \mathrm{~mm}$, wide $: 22,43 \mathrm{~mm}$, cross sectional area $: 420 \mathrm{~mm} 2$ \\
\hline Withstand compressive loads & Max. 16,46 ton & - \\
\hline Compressive strength & $3,98 \mathrm{MPa}$ & - \\
\hline Wide $: 30,9$, high $: 19,9$, foot length $: 150 \mathrm{~mm}$ \\
\hline Bear the weight & - & 1,954 ton \\
\hline Flexural strength & - & $40,44 \mathrm{~kg} / \mathrm{mm} 2$ \\
\hline
\end{tabular}

\section{3 Comboard}

After knowing the results of laboratory tests where paper board has a compressive strength withstand load of 16.46 tons and flexural strength of max. 1,954 tons while dry leaf board has a maximum compressive strength 9.8 tons and maximum flexural strength $395.9 \mathrm{~kg}$, then it was decided to experiment by combining of both paper material and dry leafs to be produced become a panel by still using the vertical cross configuration method. By knowing strength of compressive load and greater flexural strength, paper waste is used as material of internal structure in panel. While related to a more aesthetic and original appearance, dry leafs are used as an outer layer material. After several steps of vertical cross-configuration method, combination of two materials produces a new panel called a comboard. So definition of comboard is a panel that is also produced through method of vertical crossconfiguration which paper waste is used as a structural material and dry leaf is used as outer layer material. Some products that can be produced from this research include:

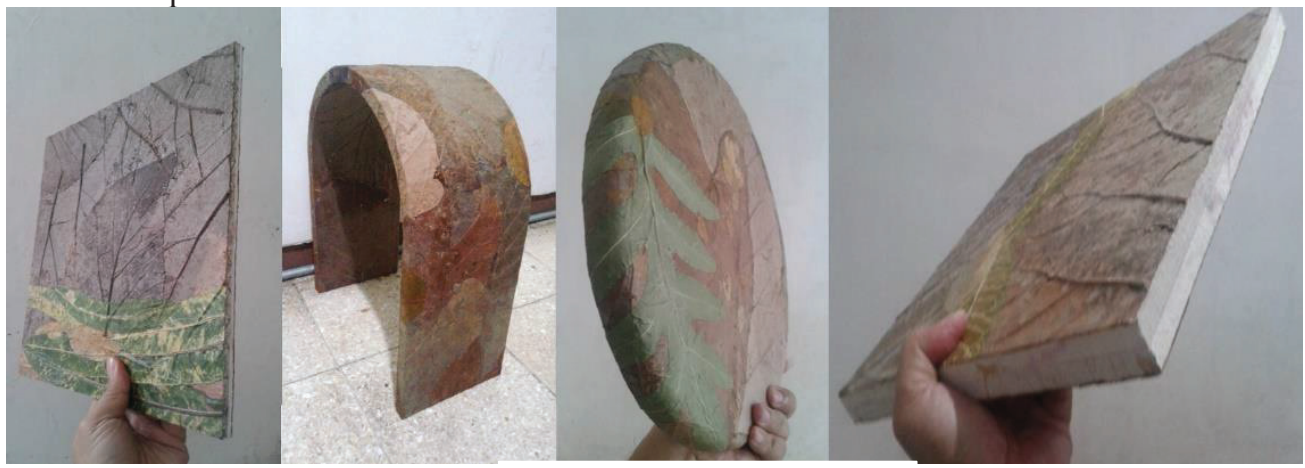

Figure 6 Comboard

Descriptions and images above shows ulat in a prouucuon perspective, application of vertical cross configuration method, production steps, and visual are not much different from a dry leaf board, the difference is only in using base ingredients and their physical abilities. When compared comboard is stronger than a dry leaf board, more aesthetic, more water resistance, faster duration of production, production step more accurate, and and same as dry leaf board and paper board, comboard can be formed more diverse (curved, wavy, sharp folding, and so on as needed).

Design direction of comboard is a value of success in construction and aesthetic applications. With stronger physical abilities and a more aesthetic visual appearance than dry leaf boards, comboard has a great opportunity to become a prospective interior design material. In the sense that comboard can be used as a material for construction and aesthetic activities that can be accounted for. 


\section{Application}

3.1 Wall material

When used as a ceiling light in a family room, comboard is designed to have dimensions of $150 \mathrm{~cm}$ long, $60 \mathrm{~cm}$ wide, and $12 \mathrm{~mm}$ thick. Here comboard is applied as a product material which suspended on ceiling. Therefore, comboard has a lighter weight to facilitate installation. While on utilization as a wall, comboard has dimensions of $400 \mathrm{~cm}$ long, $350 \mathrm{~mm}$ wide, and $12 \mathrm{~mm}$ thick. Here is need a frame for sling position of comboard as wall material. Utilization as a wall material provides opportunities for comboard to dominate visual appearance in family room. Below is its appearance:

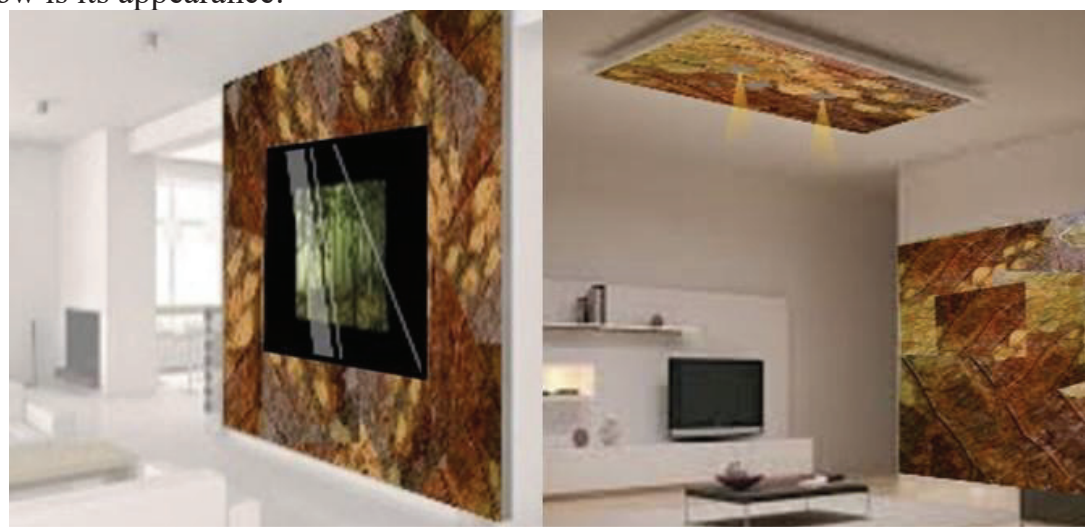

Figure 7 Comboard utilize as ceiling and wall material

On right placement of lights, comboard will be able to provide natural lighting accents optimally.

\section{2 Single seat}

Comboards can also be used as a single circular seat holder in dimension of $18 \mathrm{~cm}$ with a foot structure made of metal made of solid pipe with dimensions r. $8 \mathrm{~mm}$ and a seat thickness of $5 \mathrm{~cm}$. Here is an appearance:

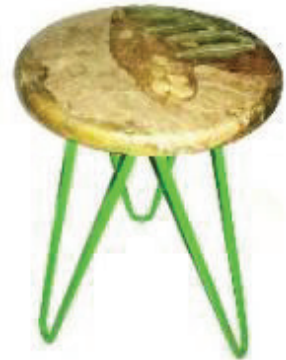

Figure 8 Comboard utilize as single seat

Manufacturing seat holder into pipe structure is done using bolt nuts. This single chair can laid out be indoor or outdoor.

\section{Conclusion}

Based on capabilities, method of vertical cross configuration will become standard implementation pattern for comboard production activities and objects of further function of this study. Vertical cross configuration is described as a method of utilizing and regulating vertical positions on a regular and systematic basis from sheets are brittle, thin, and limp to become a panel structure that strong, sturdy, and solid. The structural design resulting from method of cross vertical configuration can be applied in production patterns, visual construction and aesthetic for use in everyday life on application of interior design elements. Production process has a long duration because some stages are still done manually. An ability of both raw materials to support each other on producing quality panels which paper waste that stronger be arranged as structure and ability of dry leaf that more aesthetic is composed for visual appearance. Comboard are easy to apply, easily combined with other ingredients, do not contain hazardous chemicals, and an effort to help city environmental clean. Comboard is long resistance and means it has a long duration of use and easy maintenance.

\section{Suggestion}

Laboratory tests related to physical capabilities of comboard for further development. Machine tool application is highly recommended in next comboard production activities. 


\section{References}

Asby, Mike dan Johnson, Kara, 2009, Material and Design, USA: Elsevier, 165-169

Dick, George, 1971, Aesthetic, An Introduction, New York, USA: Pegasus Book

Gultom, Lastri Anita. Dirhamsyah, Setyawati, Dina 2013, Sifat Fisik Mekanik Papan Partikel Jerami Padi (Mechanical and physical properties of particle board rice straw), Jurnal Hutan Lestari, Universitas Tanjungpura, Vol 1 No 3, p-ISSN 2338-3127, Pontianak, Indonesia, 458 - 465

Hawari, Firman, Sachari, Agus, Nugraha, Adhi, 2017, Implementing configuration of Vertical Cross on Urban Waste Treatment as 'Aesthetic Board' for Interior Design, Academic Journal of Science, ISSN 2165-2682, US, 581-588

Mulana, Farid. Hisbullah, Iskandar, 2011, Pembuatan Papan Komposit Dari Plastik Daur Ulang dan Serbuk Kayu serta Jerami Sebagai Filler, Jurnal Rekayasa Kimia dan Lingkungan, Jurusan Teknik Kimia FakultasTeknik, Vol 8 No 1, ISSN 1412-506, Universitas Syiah Kuala, Indonesia, 17-22

Sachari, Agus,1989, Estetika Terapan, Bandug: Penerbit NOVA

Tarkono, Ali Hadi, 2016, Pemanfaatan Limbah Kelapa Sawit Sebagai Material Teknik., Jurnal Rotor, Teknik Mesin, Fakultas Teknik, Universitas Jember, Vol 9 No 2, ISSN 2460-0385, Jember, Indonesia, 94 - 99

Tata Surdia. 'Pengetahuan Bahan Teknik'. Pradnya Paramita. 229 - 235. Jakarta. Indonesia. 1984

Wong, Wucius, 1989, Beberapa Asas Merancang Trimatra, terjemahan Adjat Sakri, Bandung: Penerbit ITB, 9 17 